\title{
Epidemiology of prostate and kidney cancer in the Aboriginal population of Canada: A systematic review
}

\author{
Emily Chu Lee Wong; Anil Kapoor, MD
}

McMaster Institute of Urology, Division of Urology, Department of Surgery, McMaster University, Hamilton, ON, Canada

Cite as: Can Urol Assoc J 2017;11 (5):E222-32. http://dx.doi.org/10.5489/cuaj.4185 Published online May 9, 2017

\section{Abstract}

Introduction: Prostate and kidney cancer rates in the Aboriginal population of Canada is a growing issue.

Methods: A systematic review of prostate and kidney cancer epidemiology in the Aboriginal population of Canada was performed with international comparison and evaluation of present epidemiological disparities. PubMed, Medline, and Embase (from January 1946 to June 2016), relevant government-published reports, and the websites of organizations contributing to prostate or kidney cancer guidelines were searched. We included studies that informed any of the three epidemiological questions this review is focused on answering.

Results: Two systematic reviews, two meta-analyses, five literature reviews, and 21 single-study papers were included. The incidence and mortality rates of kidney cancer were elevated among Canadian Aboriginals when compared to the provincial or national population and to several international regions. No studies reported data on survival. Prostate cancer incidence, mortality, and survival rates were lower in Aboriginals provincially, nationally, and internationally, with incidence and survival reaching statistical significance. Elevated rate of risk factors for kidney cancer was a significant finding among Canadian Aboriginals. Aboriginals were screened for prostate cancer less than the general Canadian population, a trend also observed in the U.S.

Conclusions: The elevated incidence and mortality of kidney cancer among Canadian Aboriginals is most likely attributable to the rise in lifestyle-based risk factors. Two correlations concerning prostate cancer are made. However, due to temporal and regional disparities in data, further investigation is required to elucidate these observations.

\section{Introduction}

In Canada, the term "Aboriginal" is used to describe individuals who identify as First Nations (North American Indian), Métis, or Inuk (Inuit). ${ }^{1}$ According to the 2011 National Household Survey, 1400685 Canadians identified as being Aboriginal, comprising 4.3\% of the Canadian population. ${ }^{1}$ Provincially, Ontario has the largest population of Aboriginal people in Canada, with 301425 Aboriginal residents. ${ }^{1}$ Prostate cancer is the most commonly diagnosed malignancy among males in Canada, while kidney cancer ranks sixth. Renal cell carcinoma (RCC) is the most common morphology of kidney cancer, accounting for $80 \%$ of cases. ${ }^{2}$ Prostate and kidney cancer among Aboriginals of Canada is of particular concern due to the lack of current data on screening, treatment, and surveillance. ${ }^{3-6}$

There are three points of interest for comparison in this review:

1. Incidence, mortality, and survival rates

2. Risk factor prevalence

3. Screening guidelines

The goal of this review is to answer three epidemiological questions:

1. How do Aboriginals of Canada compare provincially, nationally, and internationally with regards to prostate and kidney cancer incidence, mortality, and survival?

2. What risk factor is the most contributory to the development of prostate and kidney cancer among Aboriginals of Canada?

3. How do Aboriginals of Canada compare internationally in following screening guidelines for prostate and kidney cancer?

\section{Methods}

Literature search strategy and quality assessment

The search terms 'aboriginal OR indigenous AND cancer AND Canada' were used. PubMed, Medline, and Embase databases were searched from the period of January 1946 to June 2016. Studies were independently screened and reviewed for inclusion and quality. The potential for bias was evaluated for included studies from which quantitative data was extracted (see Appendix 1 for detailed evaluation criteria). These studies were assessed for adequate fulfillment of all outlined criteria and inadequacy was addressed. 


\section{Study selection criteria}

Inclusion criteria were the following:

1. Systematic reviews, literature reviews, meta-analyses, and single-study papers

2. Studies reporting data on $\geq 1$ regional Aboriginal population and/or $\geq 1$ regional non-Aboriginal or general population, irrespective of region

3. Studies reporting data on prostate and/or kidney cancer in males or females $\geq 18$ years of age

4. Studies reporting age-standardized rates for incidence, mortality, or survival; method of standardization must be specified

5. Studies informing one of the three epidemiological questions of this review, as outlined

6. Studies published in English

Exclusion criteria were the following:

1. Unpublished data or papers

2. Studies reporting data on prostate and/or kidney cancer in males or females $<18$ years of age

3. Studies not informing one of the three epidemiological questions of this review, as outlined.

4. Studies not published in English

Although there are many factors that are of relevance to differences in cancer incidence, such as hereditary factors, diet, and lifestyle, this review screened papers that exclusively relate to major risk factors and screening practices for prostate and kidney cancer. The authors decided to limit the scope of the review to the three epidemiological questions in order to conduct a baseline risk analysis for future investigation.

\section{Data extraction and analysis}

Data from included studies were manually extracted onto an electronic spreadsheet accompanied by a table of results. Due to the limited number of studies available, it was not feasible to limit potential studies by specifying a minimum population. Statistical significance was determined from rate ratios and the respective confidence intervals, according to Atman and Bland's method. ${ }^{7}$ Findings with $p$ values less than 0.05 are considered statistically significant. Although data on female kidney cancer rates were provided in several studies, for sake of fair comparison to male-only prostate cancer rates, they was not included in this review.

\section{Method of age-standardization}

All incidence, mortality, and survival rates reported are age-standardized to a population specified in Table 1 and rate ratios were calculated, which is the principal summary measure of this review.

\section{Distinction between age-standardized mortality and survival}

Age-standardized mortality in all included studies is the cancer-specific rate of death standardized to a defined population other than the general or Aboriginal population. Similarly, age-standardized survival in all included studies represents the rate of cancer-specific survival standardized to a defined population other than the general or Aboriginal population.

\section{Results}

\section{Literature search results}

Searching PubMed, Medline, and Embase yielded 348 papers, 30 of which met the inclusion criteria for study selection (two systematic reviews, ${ }^{8,9}$ two meta-analyses, ${ }^{6,10}$ five literature reviews, ${ }^{2,4,5,11,12}$ and 21 single-study papers ${ }^{3,13-32}$ ) (Fig. 1).

\section{Assessment of study quality and accuracy}

Results from the evaluation of bias of studies indicate a variety of generalizability and validity issues (Table 1). Although all included studies reporting rates are retrospective, bias potential predominately exists in study design.

The conclusions made in each study, and thus this review, are susceptible to publication bias due to the generalizability of all three groups under the umbrella term 'Aboriginal.' Furthermore, the issue of generalizability of results exists in most of the studies assessed; cohort populations are geographically and/or temporally specific. It is thus difficult to elaborate on findings across several studies due to differing study designs. Nevertheless, cohort population, time period, and reference population for standardization of each respective study is made explicit in all reported rates in the respective tables. Additionally, the completeness and clarity of information was another issue raised from this assessment. Several studies failed to fully disclose the reasons for unreported data and/or unreported confidence intervals for reported data. There appear to be inherent limitations in the retrospective nature of all of these studies overall; accuracy in data linkage from registries and medical records cannot be guaranteed. In addition, data sources have a number of confounders, which further limits the conclusions made. Thus, rates reported must be interpreted with caution. 
Wong et al.

Table 1. Assessment of risk of bias

\begin{tabular}{lccc}
\hline Study & $\begin{array}{c}\text { Retrospective } \\
\text { cohort (RC), } \\
\text { case-control } \\
\text { (CC) or cross- } \\
\text { sectional } \\
\text { (CS)? }\end{array}$ & Methodology of cohort creation & Risk of bias* \\
\hline $\begin{array}{l}\text { Lix et al, } \\
2009^{3}\end{array}$ & RC & $\begin{array}{c}\text { Study relied on data from the Canadian Community } \\
\text { Health Survey (2000-2001 and 2005-2006). Aboriginals } \\
\text { self-identified on the survey. }\end{array}$ & $\begin{array}{c}\text { Time period inconsistencies exist. Generalizability of } \\
\text { results limited to off-reserve Aboriginals. Inherent } \\
\text { limitations in retrospective data review from survey. }\end{array}$ \\
\hline $\begin{array}{l}\text { Marrett \& } \\
\text { Chaudhry, } \\
2003^{13}\end{array}$ & RC & $\begin{array}{r}\text { Provincial cancer registries were used to link cancer } \\
\text { incidence and mortality files with annual Status Indian } \\
\text { membership files from 1968-1991, using personal } \\
\text { identifiers. }\end{array}$ & $\begin{array}{c}\text { Possible inadequacy in record linkage due to } \\
\text { identifier limitations. Generalizability of results } \\
\text { limited to Status Indians of Ontario. Method of } \\
\text { cohort creation does not entirely represent the Status } \\
\text { Indian population. }\end{array}$ \\
\hline
\end{tabular}

Nishri et al,
$2015^{14}$$\quad$ RC $\quad \begin{gathered}\text { Study utilized pre-existing cohort created from Marrett } \\ \text { \& Chaudhry, 2003. } .^{13} \text { Status First Nations in the Ontario } \\ \text { Cancer Registry were included for cancer cases } \\ \text { occurring from 1968-2001. }\end{gathered}$

Louchini \&
$\begin{aligned} & \text { Beaupré, } \\ & 2009^{15}\end{aligned}$$\quad \begin{aligned} & \text { Québec's tumour and mortality files from 1984-2004 } \\ & \text { were used, which contained residence information } \\ & \text { used to identify on- and off-reserve Aboriginals. }\end{aligned}$

Possible inadequacy in record linkage due to identifier limitations. Generalizability of results limited to Status First Nations of Ontario.

Unreported data on some reserve populations.

Generalizability of results limited to Québec

Aboriginals living on-reserve and in Northern

villages. Inherent limitations in retrospective data review from registry.

Louchini \&
$\begin{aligned} & \text { Beaupré, } \\ & 2008^{16}\end{aligned}$

Unreported data on some reserve populations.

Generalizability of results limited to Québec

Aboriginals living on-reserve and in Northern

villages. Inherent limitations in retrospective data review from registry.

$\begin{aligned} & \text { Sanchez- } \\ & \text { Ramirez et } \\ & \text { al, 2016 }\end{aligned}$
RC $\begin{gathered}\text { Patients were identified as Métis by the Alberta } \\ \text { Ministry of Health through Patient Health Number. } \\ \text { Métis cancer cases from 2007-2012 were identified } \\ \text { through the MNA registry. }\end{gathered}$

National and provincial cancer registries were used to Kue Young RC identify ethnicity, including the Alaska Native Tumor et al, 2016 ${ }^{11}$ RC Registry, Canadian Cancer Registry, and Danish Cancer Registry.
Generalizability of results limited to Métis of Alberta. Method of cohort creation does not entirely represent the Métis population. Inherent limitations in retrospective data review from registry.

Inconsistency in rate reporting between cohort and comparison group. Incomplete cohort and comparison data for certain time periods. Confidence intervals not provided. Inherent limitations in retrospective data review from registry.

\section{Life expectancy}

New Zealand (2001-2002): Statistics New Zealand

United States (2001): Centers for Disease Control and Prevention

Australia (2000): Australian Institute of Health and Welfare

Canada (2000): Health Canada

\section{Bramley et} al, $2004^{18}$
Mortality data

New Zealand (1999): New Zealand Health Information Service

United States (1999): National Center for Health Statistics

Australia (1999): Australian Institute of Health and Welfare

Canada (1999): Statistics Canada (data available for on-reserve First Nations only)
Confidence intervals not provided. Generalizability of results limited to the Maori population of New Zealand, Australian Aboriginals and Torres Strait Islanders, on-reserve First Nations of Canada, and American Indians and Alaskan Natives of the U.S. Inherent limitations in retrospective data review from several different registries. 
Table 1 (cont'd). Assessment of risk of bias

\begin{tabular}{lccc}
\hline Study & $\begin{array}{c}\text { Retrospective } \\
\text { cohort (RC), } \\
\text { case-control } \\
\text { (C) or cross- } \\
\text { sectional } \\
\text { (CS)? }\end{array}$ & Methodology of cohort creation & Risk of bias* \\
\hline Espey et al, & CS & $\begin{array}{c}\text { Death certificate records from five regions with high } \\
\text { concentrations of Alaska Natives and American Indians } \\
\text { were analyzed from the National Center for Health } \\
2005^{19}\end{array}$ & $\begin{array}{c}\text { Confidence intervals not reported. Inherent } \\
\text { limitations in retrospective data review of death } \\
\text { certificates. }\end{array}$
\end{tabular}

Case: The Montana Central Tumour Registry and the Indian Health Service medical records from January 1, 1984 to December 31, 1993 were reviewed for American Indian malignant cancer diagnoses. Dennis, American Indians must reside in one of the three $2000^{20}$ CC regions of Montana with reservations.

Control: The same methodology was used for nonAmerican Indians with malignant cancer diagnoses within the same time period. Controls were matched to cases based on outlined criteria.

\begin{tabular}{|c|c|c|c|}
\hline $\begin{array}{l}\text { Young } \\
\text { \& Frank, } \\
1983^{24}\end{array}$ & $\mathrm{RC}$ & $\begin{array}{l}\text { Mortalities in the Sioux Lookout Zone of Northwestern } \\
\text { Ontario, discharges from the Sioux Lookout Zone } \\
\text { hospital (1970-1974) and the Hospital Medical Records } \\
\text { Institute (1975) and logged encounters (1978) from } \\
\text { Indians were used. }\end{array}$ & $\begin{array}{l}\text { Inclusion and exclusion criteria for the cohort group } \\
\text { unclear. Inconsistency in rate reporting between } \\
\text { cohort and comparison group. Confidence intervals } \\
\text { not reported. Generalizability of results limited } \\
\text { to Indians residing in the Sioux Lookout Zone } \\
\text { of Northwestern Ontario. Inherent limitations in } \\
\text { retrospective data review from several different } \\
\text { sources. }\end{array}$ \\
\hline $\begin{array}{l}\text { Morrell et } \\
\text { al, } 2012^{28}\end{array}$ & CS & $\begin{array}{c}\text { The New South Wales Cancer Registry was used to } \\
\text { identify cancer diagnoses (1999-2008) based on status } \\
\text { identification. }\end{array}$ & $\begin{array}{l}\text { Data limited to Aboriginals of New South Wales who } \\
\text { self-identify. Inherent limitations in retrospective data } \\
\text { review of death certificates. }\end{array}$ \\
\hline $\begin{array}{l}\text { Physicians } \\
\text { for a } \\
\text { Smoke-Free } \\
\text { Canada, } \\
2013^{35}\end{array}$ & $\mathrm{RC}$ & $\begin{array}{c}\text { Smoking rates were based on the } 2006 \text { Census } \\
\text { definition of 'Aboriginal' and estimates were approved } \\
\text { by Statistics Canada. }\end{array}$ & Of those applicable, none were identified. \\
\hline $\begin{array}{l}\text { Withrow et } \\
\text { al, } 2014^{29}\end{array}$ & $\mathrm{RC}$ & $\begin{array}{l}\text { Combined Canadian Community Health Surveys } \\
\text { (2007-2011) were used to analyze risk factors. } \\
\text { Aboriginals self-identified on the survey. }\end{array}$ & $\begin{array}{l}\text { Generalizability of results limited to off-reserve First } \\
\text { Nations and Métis of Ontario. Inherent limitations in } \\
\text { retrospective survey data review. }\end{array}$ \\
\hline
\end{tabular}

Epidemiological question 1: How do Aboriginals of Canada compare provincially, nationally, and internationally with regards to prostate and kidney cancer incidence, mortality, and survival?

\section{Prostate cancer}

Eleven studies reported prostate cancer incidence, mortality, and/or survival during the time period 1968-2012. The age-adjusted rate ratios for incidence was decreased among Aboriginals, ranging from 0.53 to 1.10 and was significantly less than 1.0 in six studies (Table 2). Although several explanations may account for decreased prostate cancer incidence reported by most studies, competing causes of death in the Aboriginal population seems the most probable. In a population with elevated comorbidities, such as diabetes mellitus, individuals who may have otherwise developed prostate cancer in their lifetime may account for this deficit in incidence.

Mortality and survival were both decreased among Canadian Aboriginals. The age-adjusted rate ratios for mortality ranged from 0.64 to 0.90 in Canadian Aboriginals, although none were statistically significant (Table 3 ). However, mortality among Aboriginal populations internationally was elevated, with the exception of one study, ranging from $0.41-1.86$, and significantly greater than 1.0 in two studies. Survival data was found for Aboriginals of Ontario, Montana, and New South Wales. The age-adjusted rate ratios ranged from $0.62-0.88$, which were all significantly less than 1.0 (Table 4).

Overall, rate ratios for Aboriginal incidence, mortality, and survival were either less than or not significantly greater than 1.0. Differences in incidence and survival were statistic- 


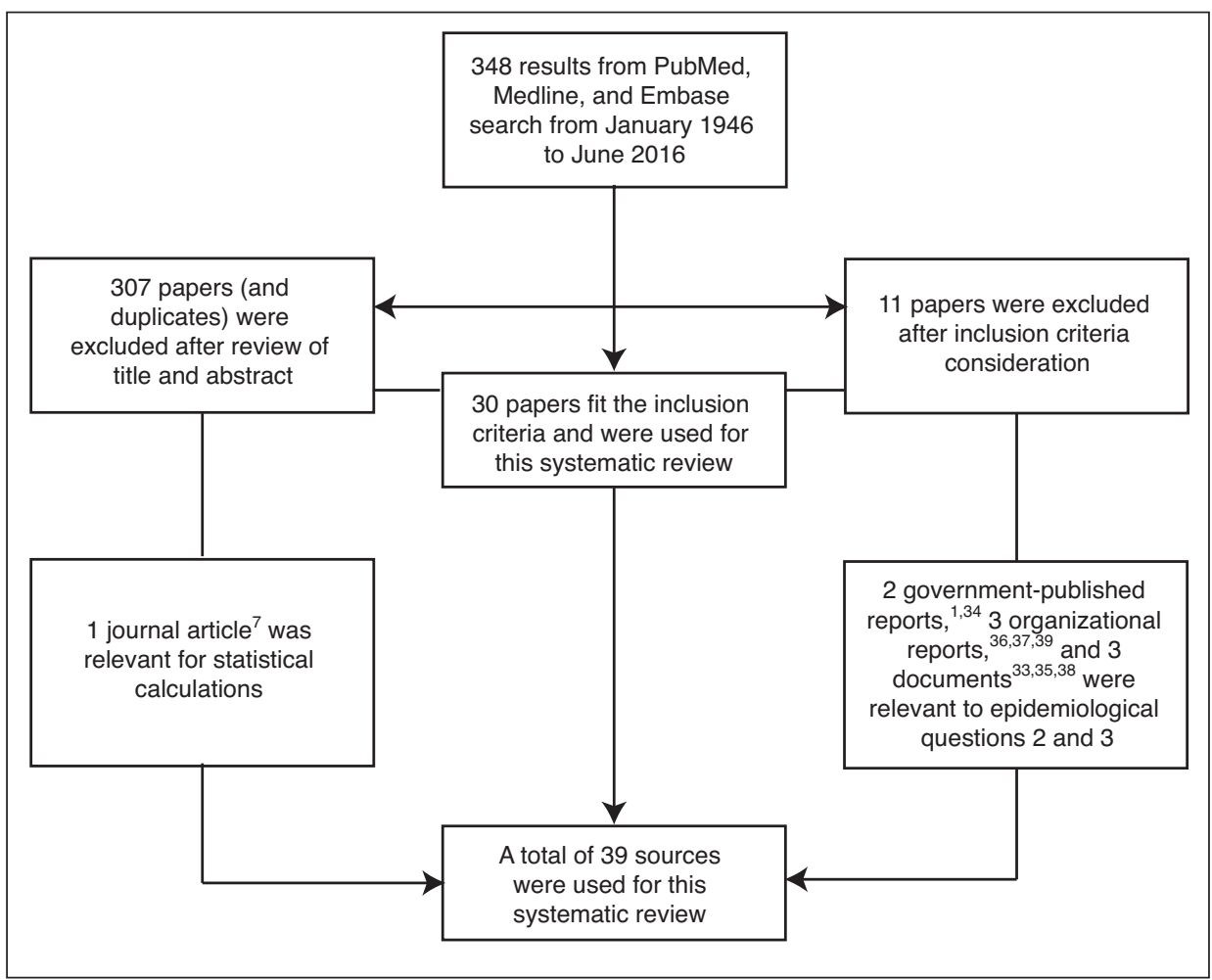

Fig. 1. Flow chart of study selection and inclusion of other sources.

ally significant. However, p values could not be affirmed for half the incidence rates. ${ }^{11,24}$ No statistically significant difference was found for prostate cancer mortality in Canada. $P$ values for half of the reported mortality rates from three studies could not be determined. ${ }^{18,19,24}$ Due to the lack of statistically significant mortality data, other factors that influence prostate cancer incidence and mortality in Aboriginals cannot be ruled out.

\section{Kidney cancer}

Seven studies reported data on kidney cancer incidence and mortality during the time period 1968-2008. All studies had age-adjusted rate ratios for incidence that were greater than 1.0, ranging from 1.18-2.06. However, rates were significantly greater than 1.0 in two studies and statistical significance could not be determined for another two studies. Age-adjusted rate ratios for mortality were greater than 1.0, ranging from 1.24-1.70. These were significant in three studies, while statistical significance could not be determined for three studies. Data on survival was not found.

In correspondence with this, a meta-analysis of cancer incidence found significantly increased incidence in Aboriginals of the U.S. and Canada. ${ }^{10}$ However, lung cancer was significantly lower, suggesting that increased kidney cancer incidence in the Aboriginal population may be attributable to factors other than smoking. ${ }^{10}$
Epidemiological question 2: What risk factor is the most contributory to the development of prostate and kidney cancer among Aboriginals of Canada?

\section{Prostate cancer}

Risk factors surrounding the development of prostate cancer are lifestyle- and hereditary-based, having a genetic (i.e., inheritance of certain prostate cancer susceptible genes), familial (i.e., positive family history of prostate cancer), inflammatory, infectious, androgen-related, or dietary premise. $^{4,5}$ One of the strongest risk factors for prostate cancer is age; the majority of diagnoses occur in men over 55 , particularly at $70-74$ years of age. ${ }^{5} \mathrm{~A}$ meta-analysis reported that Aboriginals of Canada have the highest odds ratio (OR) for developing prostate cancer compared to any other race, with an adjusted OR of 1.2. ${ }^{6}$ This is 0.2 greater than the OR of the black population, who more commonly develop prostate cancer. ${ }^{5,6}$ Since the ORs reported were adjusted to the aforementioned risk factors, including income and certain foods, this indicates a shift in focus towards environmental factors that potentially attribute to the development of prostate cancer in Canada. ${ }^{6}$ Although an OR $>1.0$ reflects an increased chance of Aboriginals developing prostate cancer compared to non-Aboriginals, it does not indicate elevated incidence, as the ORs are calculated in the context of risk factor exposure and not cancer diagnosis.

\section{Kidney cancer}

Although the etiology of kidney cancer is unclear, well-established risk factors for RCC, such as cigarette smoking, obesity, and hypertension (which are lifestyle-based) have been identified through the literature. ${ }^{12}$ There is considerable evidence to strongly link tobacco exposure and the development of RCC, accounting for up to $20 \%$ of cases. ${ }^{33,34}$ Smoking was twice as prevalent among Canadian Aboriginals from 2006-2010. ${ }^{35}$ Nearly $50 \%$ of Inuit, $40 \%$ of First Nations, and $37 \%$ of Métis smoked compared to only $20.5 \%$ of non-Aboriginals. ${ }^{35}$ Elevated rates of obesity and hypertension were observed as well. ${ }^{3,29}$ All risk factor rate ratios are greater than or approaching 1.0, particularly for cigarette smoking; $89 \%$ of rates (25/28) were statistically significant (Table 5). Monitoring these lifestyle-based risk factors in the Aboriginal population of Canada is an imperative task, as observed in its cumulative increase. 
Table 2. Age-standardized prostate cancer incidence rates per 100000 among the male Aboriginal and non-Aboriginal or general population (comparative) by region and time period

\begin{tabular}{|c|c|c|c|c|c|c|c|c|}
\hline \multirow[b]{2}{*}{ Region } & \multicolumn{2}{|r|}{ Aboriginal population } & \multicolumn{2}{|c|}{ Comparative population } & \multirow{2}{*}{$\begin{array}{l}\text { Aboriginal } \\
\text { ASR (95\% } \\
\text { Cl) }\end{array}$} & \multirow{2}{*}{$\begin{array}{l}\text { Comparative } \\
\text { ASR }(95 \% \mathrm{CI})\end{array}$} & \multirow[b]{2}{*}{$\operatorname{RR}(95 \% \mathrm{Cl}) *$} & \multirow[b]{2}{*}{$\mathbf{p}^{* *}$} \\
\hline & $\begin{array}{l}\text { Time } \\
\text { period }\end{array}$ & Definition & Time period & Definition & & & & \\
\hline Ontario $^{a, 13}$ & 1968-1991 & First Nations, Inuit and Métis & 1968-1991 & $\begin{array}{l}\text { Non- } \\
\text { Aboriginals } \\
\text { of Ontario }\end{array}$ & $\begin{array}{c}25.39 \\
n_{s}=174 \\
n_{p}=141290\end{array}$ & 44.88 & $\begin{array}{c}0.57 \\
(0.48-0.66)\end{array}$ & $<0.0001$ \\
\hline Ontario $^{\mathrm{b}, 24}$ & 1972-1981 & $\begin{array}{l}\text { Indians residing in the } \\
\text { Sioux Lookout Zone in } \\
\text { Northwestern Ontario }\end{array}$ & $1976-1978$ & $\begin{array}{c}\text { General } \\
\text { Canadian }\end{array}$ & $\begin{array}{c}0.65 \\
\left(\text { Ranked } 2^{\text {nd }}\right) \\
n_{s}=6\end{array}$ & Ranked $3^{\text {rd }}$ & $\mathrm{N} / \mathrm{A}$ & $\mathrm{N} / \mathrm{A}$ \\
\hline Quebec $^{c, 15}$ & 1988-2004 & $\begin{array}{c}\text { Status Indians and Inuit } \\
\text { living on reserves and in } \\
\text { Québec's Northern villages: } \\
\text { Abenaki, Algonquin, } \\
\text { Atikamekw, Cree, Huron- } \\
\text { Wendats, Inuit, Malecite, } \\
\text { Micmac, Mohawk, Innu, and } \\
\text { Naskapi }\end{array}$ & 1988-2004 & $\begin{array}{l}\text { General } \\
\text { Quebec }\end{array}$ & $\begin{array}{c}64.8 \\
(51.1-78.6) \\
n_{s}=88 \\
n_{p}=57,744\end{array}$ & $\begin{array}{c}91.7 \\
(90.9-92.5)\end{array}$ & $\begin{array}{c}0.71 \\
(0.56-0.85)\end{array}$ & 0.0012 \\
\hline Quebec $^{c, 16}$ & 1988-2004 & $\begin{array}{l}\text { Status Indians and Inuit } \\
\text { living on reserves and in } \\
\text { Québec's Northern villages: } \\
\text { Abenaki, Algonquin, } \\
\text { Atikamekw, Cree, Huron- } \\
\text { Wendats, Inuit, Malecite, } \\
\text { Micmac, Mohawk, Innu, and } \\
\text { Naskapi }\end{array}$ & 1988-2004 & $\begin{array}{l}\text { General } \\
\text { Quebec }\end{array}$ & $\begin{array}{c}47.4 \\
(37.5-57.3) \\
n_{s}=88\end{array}$ & $\begin{array}{c}67.1 \\
(66.5-67.7)\end{array}$ & $\begin{array}{c}0.71 \\
(0.56-0.85)\end{array}$ & 0.0012 \\
\hline Alberta $^{c, 17}$ & 2007-2012 & Métis & 2007-2012 & $\begin{array}{c}\text { Non-Métis of } \\
\text { Alberta }\end{array}$ & $\begin{array}{c}91.9 \\
(65.4-118.3) \\
n_{s}=53 \\
n_{p}=23,793\end{array}$ & $\begin{array}{c}122.7 \\
(120.5-124.8) \\
n_{s}=13266 \\
n_{p}=3676253\end{array}$ & $\begin{array}{c}0.75 \\
(0.54-0.95)\end{array}$ & 0.0477 \\
\hline Yukon $^{\mathrm{d}, 11}$ & 1989-2008 & Inuit and Métis & 2000-2009 & $\begin{array}{l}\text { General } \\
\text { Canadian }\end{array}$ & N/A & $\begin{array}{c}58.0 \\
n_{p}=31697\end{array}$ & $\mathrm{~N} / \mathrm{A}$ & $\mathrm{N} / \mathrm{A}$ \\
\hline $\begin{array}{l}\text { Alaska and } \\
\text { North West } \\
\text { Territories }^{\mathrm{d}, 11}\end{array}$ & 1989-2008 & $\begin{array}{c}\text { Athabaskan (North } \\
\text { American Indian) }\end{array}$ & 2000-2009 & $\begin{array}{c}\text { General } \\
\text { Canadian }\end{array}$ & 71.2 & $\begin{array}{c}\quad 64.5 \\
n_{p}=662061 \\
\text { and } 42633\end{array}$ & 1.10 & $\mathrm{~N} / \mathrm{A}$ \\
\hline $\begin{array}{l}\text { Alaska, } \\
\text { North West } \\
\text { Territories, } \\
\text { Nunavut and } \\
\text { Greenland }^{\mathrm{d}, 11}\end{array}$ & 1989-2008 & Circumpolar (Inuit) & 2000-2009 & $\begin{array}{c}\text { General } \\
\text { Canadian }\end{array}$ & 14.9 & $\begin{array}{c}19.5 \\
\mathrm{n}_{\mathrm{p}}=662061 \\
42633,29 \\
982, \text { and } 56 \\
577\end{array}$ & 0.76 & $\mathrm{~N} / \mathrm{A}$ \\
\hline $\begin{array}{l}\text { Chukotka, } \\
\text { Russiad }^{\mathrm{d}, 11}\end{array}$ & 2000-2009 & $\begin{array}{l}\text { Indigenous peoples of } \\
\text { Chukotka }\end{array}$ & 2000-2009 & $\begin{array}{l}\text { General } \\
\text { Chukotka }\end{array}$ & 10.6 & $\begin{array}{c}20.1 \\
n_{p}=52399\end{array}$ & 0.53 & $\mathrm{~N} / \mathrm{A}$ \\
\hline $\begin{array}{l}\text { New South } \\
\text { Wales, } \\
\text { Australia }{ }^{e, 28}\end{array}$ & 1999-2007 & Aboriginal & 1999-2007 & $\begin{array}{c}\text { Non- } \\
\text { Aboriginals } \\
\text { of New } \\
\text { South Wales }\end{array}$ & $\begin{array}{c}144.5 \\
(120.0- \\
169.0) \\
n_{s}=239\end{array}$ & $\begin{array}{c}176.2 \\
(169.0- \\
179.8)^{* * *}\end{array}$ & $\begin{array}{c}0.82 \\
(0.71-0.94)\end{array}$ & 0.0057 \\
\hline $\begin{array}{l}\text { te ratio (RR) wa } \\
\mathrm{n} \text { Aboriginal AS } \\
\text { iance between a } \\
\text { ermined by divic } \\
\text { up; 'standardize } \\
\text { isus population. } \\
\text { : not available; }\end{array}$ & $\begin{array}{l}\text { termined by di } \\
\text { nd Comparativ } \\
\text { groups not acc } \\
\text { Aboriginal AS } \\
\text { the } 1991 \text { Cana } \\
\text { e p value prese } \\
\text { relative risk. }\end{array}$ & $\begin{array}{l}\text { lividing Aboriginal ASR by Comparative } \\
\text { ve ASR. All RRs were rounded to the nea } \\
\text { counted for in the studies. Significance is } \\
\text { SR by RR. aStandardized to the World St } \\
\text { adian Census population; }{ }^{\text {dstandardized }} \text { stan } \\
\text { ented is stated from the source. ASR: ag }\end{array}$ & $\begin{array}{l}\text { with the } 95 \% \\
\text { hundredth; }{ }^{* *} \\
\text { cated in boldf } \\
\text { rd Population; } \\
\text { e International } \\
\text { ndardized rate }\end{array}$ & $\begin{array}{l}\text { idence Interval } \\
\text { ences in ASRs v } \\
\text { Il values obtain } \\
\text { dardized to the } \\
\text { cy of Research } \\
\text { onfidence inter }\end{array}$ & $\begin{array}{l}\text { the RR determir } \\
\text { ested for signific } \\
\text { ere rounded to th } \\
\text { of the } 1976,197 \\
\text { ancer World Star } \\
\text { s: number of inci }\end{array}$ & $\begin{array}{l}\text { nce assuming indep } \\
\text { nearest ten-thousar } \\
\text {, and } 1978 \text { Canadian } \\
\text { ence, mortality, or s }\end{array}$ & $\begin{array}{l}\text { with the values } \\
\text { dence of ASRs a } \\
\text { h; ***comparati } \\
\text { tes of the respec } \\
\text { ardized to the } 20 \\
\text { ival cases; } n p: p\end{array}$ & $\begin{array}{l}\text { e } \mathrm{Cl} \\
\text { any } \\
\text { ASR was } \\
\text { e age } \\
\text { Australian } \\
\text { „lation size; }\end{array}$ \\
\hline
\end{tabular}


Wong et al.

Table 3. Age-standardized prostate cancer mortality rates per 100000 among the male Aboriginal and non-Aboriginal or general population (comparative) by region and time period

\begin{tabular}{|c|c|c|c|c|c|c|c|c|}
\hline \multirow[b]{2}{*}{ Region } & \multicolumn{2}{|r|}{ Aboriginal population } & \multicolumn{2}{|c|}{ Comparative population } & \multirow{2}{*}{$\begin{array}{c}\text { Aboriginal } \\
\text { ASR }(95 \% \mathrm{Cl})\end{array}$} & \multirow{2}{*}{$\begin{array}{l}\text { Comparative } \\
\text { ASR }(95 \% \text { Cl) }\end{array}$} & \multirow[b]{2}{*}{$\operatorname{RR}(95 \% \mathrm{CI})^{*}$} & \multirow[b]{2}{*}{$\mathbf{p}^{* *}$} \\
\hline & $\begin{array}{l}\text { Time } \\
\text { period }\end{array}$ & Definition & $\begin{array}{l}\text { Time } \\
\text { period }\end{array}$ & Definition & & & & \\
\hline Ontario ${ }^{\mathrm{a}, 13}$ & 1968-1991 & First Nations, Inuit, and Métis & 1968-1991 & $\begin{array}{l}\text { Non-First } \\
\text { Nations, Inuit } \\
\text { and Métis }\end{array}$ & $\begin{array}{c}11.61 \\
n_{s}=84 \\
n_{p}=141290\end{array}$ & 14.35 & $\begin{array}{c}0.81 \\
(0.65-1.01)\end{array}$ & 0.0590 \\
\hline Ontario ${ }^{b, 24}$ & 1972-1981 & $\begin{array}{c}\text { Indians residing in the Sioux } \\
\text { Lookout Zone in northwestern } \\
\text { Ontario }\end{array}$ & $1976-1978$ & $\begin{array}{c}\text { General } \\
\text { Canadian }\end{array}$ & $\begin{array}{c}0.93 \\
\left(\text { Ranked } 4^{\text {th }} \text { ) }\right. \\
n_{s}=3\end{array}$ & Ranked $2^{\text {nd }}$ & $\mathrm{N} / \mathrm{A}$ & $\mathrm{N} / \mathrm{A}$ \\
\hline Quebec ${ }^{c, 15}$ & 1988-2004 & $\begin{array}{c}\text { Status Indians and Inuit living } \\
\text { on reserves and in Québec's } \\
\text { Northern villages: Abenaki, } \\
\text { Algonquin, Atikamekw, } \\
\text { Cree, Huron-Wendats, Inuit, } \\
\text { Malecite, Micmac, Mohawk, } \\
\text { Innu, and Naskapi }\end{array}$ & 1988-2004 & $\begin{array}{l}\text { General } \\
\text { Quebec }\end{array}$ & $\begin{array}{c}21.1 \\
(13.2-29.0) \\
n_{s}=28 \\
n_{p}=57744\end{array}$ & $\begin{array}{c}23.6 \\
(23.2-24.0)\end{array}$ & $\begin{array}{c}0.89 \\
(0.57-1.21)\end{array}$ & 0.5518 \\
\hline Quebec $^{c, 16}$ & 1988-2004 & $\begin{array}{c}\text { Status Indians and Inuit living } \\
\text { on reserves and in Québec's } \\
\text { Northern villages: Abenaki, } \\
\text { Algonquin, Atikamekw, } \\
\text { Cree, Huron-Wendats, Inuit, } \\
\text { Malecite, Micmac, Mohawk, } \\
\text { Innu, and Naskapi }\end{array}$ & 1988-2004 & $\begin{array}{l}\text { General } \\
\text { Quebec }\end{array}$ & $\begin{array}{c}15.2 \\
(9.6-20.9) \\
n_{s}=28\end{array}$ & $\begin{array}{c}16.8 \\
(16.5-17.1)\end{array}$ & $\begin{array}{c}0.90 \\
(0.58-1.22)\end{array}$ & 0.5888 \\
\hline Alberta ${ }^{c, 17}$ & 2007-2012 & Métis & $2007-2012$ & Non-Métis & $\begin{array}{c}13.9 \\
(0.4-27.5) \\
n_{p}=23,793\end{array}$ & $\begin{array}{c}21.9 \\
(20.9-22.8) \\
n_{p}=3676253\end{array}$ & $\begin{array}{c}0.64 \\
(0.02-1.21)\end{array}$ & 0.6832 \\
\hline Alaska $^{e, 19}$ & 1990-1995 & $\begin{array}{l}\text { Alaska Natives and American } \\
\text { Indians residing in Alaska }\end{array}$ & 1990-1995 & General U.S. & $\begin{array}{c}25.51 \\
n_{s}=334\end{array}$ & $\begin{array}{c}38.71 \\
n_{s}=204418\end{array}$ & 0.66 & $\mathrm{~N} / \mathrm{A}$ \\
\hline Alaska $^{\mathrm{e}, 19}$ & 1996-2001 & $\begin{array}{l}\text { Alaska Natives and American } \\
\text { Indians residing in Alaska }\end{array}$ & 1996-2001 & General U.S. & $\begin{array}{c}23.5 \\
n_{s}=343\end{array}$ & $\begin{array}{c}32.2 \\
n_{s}=192739\end{array}$ & $\begin{array}{c}0.73 \\
(0.65-0.82)\end{array}$ & $<0.0001$ \\
\hline $\begin{array}{l}\text { New } \\
\text { Zealandf,18 }\end{array}$ & 1999 & Maori & 1999 & Non-Maori & 14.8 & 9.6 & 1.54 & N/A \\
\hline Canada ${ }^{f, 18}$ & 1999 & First Nations living on reserves & 1999 & $\begin{array}{l}\text { Non-First } \\
\text { Nations }\end{array}$ & 8.8 & 7.4 & 1.19 & $\mathrm{~N} / \mathrm{A}$ \\
\hline $\begin{array}{l}\text { United } \\
\text { States }\end{array}$ & 1999 & $\begin{array}{l}\text { Alaska Natives and American } \\
\text { Indians }\end{array}$ & 1999 & $\begin{array}{l}\text { Non-Alaska } \\
\text { Native and } \\
\text { American } \\
\text { Indian }\end{array}$ & 2.9 & 7.0 & 0.41 & $\mathrm{~N} / \mathrm{A}$ \\
\hline $\begin{array}{l}\text { New South } \\
\text { Wales, } \\
\text { Australiag }^{\mathrm{g}, 28}\end{array}$ & 1999-2007 & Aboriginals & 1999-2007 & $\begin{array}{c}\text { Non- } \\
\text { Aboriginals } \\
\text { of New } \\
\text { South Wales }\end{array}$ & $\begin{array}{c}57.1 \\
(42.6-74.5) \\
n_{s}=65\end{array}$ & $\begin{array}{c}30.70 \\
(29.79- \\
31.43)^{* * *}\end{array}$ & $\begin{array}{c}1.86 \\
(1.43-2.37)\end{array}$ & $<0.0001$ \\
\hline
\end{tabular}

* Rate ratio (RR) was determined by dividing Aboriginal ASR by Comparative ASR, with the $95 \%$ Confidence Interval (Cl) of the RR determined in a similar manner with the values of the Cl from Aboriginal ASR and Comparative ASR. All RRs were rounded to the nearest hundredth; ${ }^{* *}$ differences in ASRs were tested for significance assuming independence of ASRs and any variance between age groups not accounted for in the studies. Significance is indicated in boldface. All values obtained were rounded to the nearest ten-thousandth; ${ }^{* * *}$ comparative ASR was determined by dividing Aboriginal ASR by RR. aStandardized to the World Standard Population; 'bstandardized to the mean of the 1976, 1977, and 1978 Canadian rates of the respective

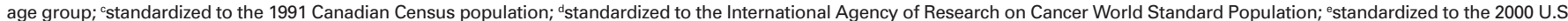

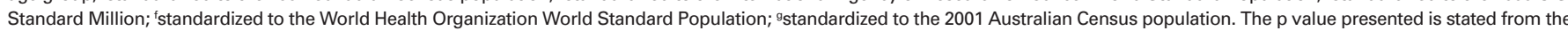
source. ASR: age-standardized rate; Cl: confidence interval; ns: number of incidence, mortality, or survival cases; np: population size; N/A: not available; RR: relative risk.

Epidemiological question 3: How do Aboriginals of Canada compare internationally in following screening guidelines for prostate and kidney cancer?

\section{Prostate cancer}

According to a systematic review resulting in 2011 screening guidelines, the Canadian Urological Association recommends prostate-specific antigen (PSA) screening and digital rectal examination (DRE) in men aged 50 years or older who, at minimum, are expected to live for 10 years. ${ }^{8}$ This is further supported by the American Cancer Society, American Urological Association, and Canadian Cancer Society, which all agree that the decision to have a PSA test should be one that is informed with both the risks and benefits of the test. ${ }^{9}$

When two reports on screening in Aboriginal Canadians were compared, a significant disparity in screening use was apparent. ${ }^{36,37}$ Only $23.4 \%$ of First Nations men in Canada had 


\begin{tabular}{|c|c|c|c|c|c|c|c|c|}
\hline \multirow[b]{2}{*}{ Region } & \multicolumn{2}{|c|}{ Aboriginal population } & \multicolumn{2}{|c|}{ Comparative population } & \multirow{2}{*}{$\begin{array}{c}\text { Aboriginal } \\
\text { ASR }(95 \% \mathrm{CI})\end{array}$} & \multirow{2}{*}{$\begin{array}{l}\text { Comparative } \\
\text { ASR (95\% Cl) }\end{array}$} & \multirow[b]{2}{*}{$\mathbf{R R}(95 \% \mathrm{Cl}) *$} & \multirow[b]{2}{*}{$\mathbf{p}^{* *}$} \\
\hline & $\begin{array}{l}\text { Time } \\
\text { period }\end{array}$ & Definition & $\begin{array}{l}\text { Time } \\
\text { period }\end{array}$ & Definition & & & & \\
\hline Ontario ${ }^{\mathrm{a}, 14}$ & 1968-1991 & $\begin{array}{l}\text { First Nations, Inuit, } \\
\text { and Métis }\end{array}$ & 1968-1991 & $\begin{array}{l}\text { Non-First Nations, } \\
\text { Inuit, and Métis }\end{array}$ & $\begin{array}{c}41.6 \\
(29.5-58.6) \\
n_{s}=104 \\
n_{p}=141290\end{array}$ & $\begin{array}{c}63.8 \\
(63.0-64.6)\end{array}$ & $\begin{array}{c}0.65 \\
(0.47-0.91)\end{array}$ & 0.0083 \\
\hline Ontario ${ }^{\mathrm{a}, 14}$ & 1992-2001 & $\begin{array}{l}\text { First Nations, Inuit, } \\
\text { and Métis }\end{array}$ & 1992-2001 & $\begin{array}{l}\text { Non-First Nations, } \\
\text { Inuit, and Métis }\end{array}$ & $\begin{array}{c}72.0 \\
(63.5-81.8) \\
n_{s}=163\end{array}$ & $\begin{array}{c}85.2 \\
(84.8-85.6)\end{array}$ & $\begin{array}{c}0.85 \\
(0.75-0.96)\end{array}$ & 0.0085 \\
\hline Montana $a^{\mathrm{b}, 20}$ & 1984-1993 & $\begin{array}{l}\text { American Indians } \\
\text { residing in Montana }\end{array}$ & 1984-1993 & $\begin{array}{l}\text { Non-American Indians } \\
\text { residing in Montana }\end{array}$ & $\begin{array}{c}39 \\
n_{s}=63 \\
n_{p}=35649\end{array}$ & $\begin{array}{c}63 \\
n_{s}=63\end{array}$ & 0.62 & $<0.01$ \\
\hline $\begin{array}{l}\text { New South } \\
\text { Wales, } \\
\text { Australiaac,28 }\end{array}$ & 1999-2007 & Aboriginals & 1999-2007 & $\begin{array}{l}\text { Non-Aboriginals of } \\
\text { New South Wales }\end{array}$ & $\begin{array}{c}77.6 \\
(70.9-84.3)\end{array}$ & $\begin{array}{c}87.7 \\
(87.3-88.1)\end{array}$ & $\begin{array}{c}0.88 \\
(0.81-0.96)\end{array}$ & 0.0032 \\
\hline
\end{tabular}

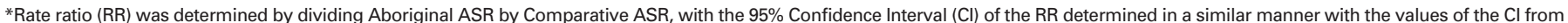

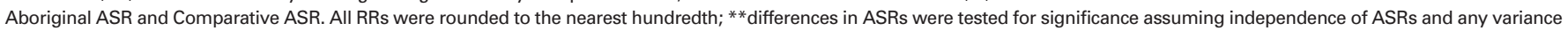

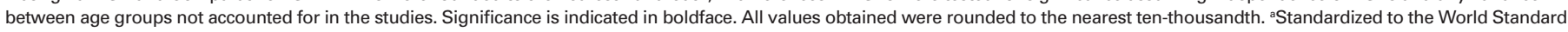

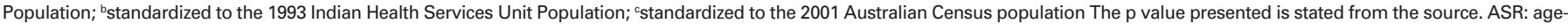
standardized rate; $\mathrm{Cl}$ : confidence interval; ns: number of incidence, mortality, or survival cases; np: population size; N/A: not available; RR: relative risk.

a PSA test or DRE, which was below the national average of $35-75 \%$ in men $50-75$ years of age, province-dependent. ${ }^{36,37}$ Compared to data reported by two studies, one during 2008 on the Chamorro men of Guam and another during 2005 on Native American men of the U.S., First Nations screening in Canada was twofold and threefold lower, respectively. ${ }^{30,31}$ However, screening among Canadian First Nations was better compared to Indigenous Nigerians of the U.S. ${ }^{32}$ Statistically, $91 \%$ of Indigenous Nigerians had never been tested for prostate cancer, $6 \%$ had been tested in the previous year, and 3\% were tested longer than a year ago. ${ }^{32}$ Overall, the study found that Indigenous Nigerian men in the U.S. were less likely to be screened for prostate cancer. ${ }^{32}$

\section{Kidney cancer}

According to Kidney Cancer Canada, there are no established or recommended screening methods to detect kidney cancer. ${ }^{33}$ This is attributable primarily to the lack of evidence to suggest a reduced risk of mortality. ${ }^{38}$ Incidental findings from imaging tests or urinalysis are the most common source of diagnosis due to the asymptomatic nature of kidney cancer. ${ }^{38}$ As it is difficult to accurately correlate rates of diagnostic test use without knowing the respective clinical indications, screening comparison for kidney cancer was not conducted for this review.

\section{Interpretation}

Correlation between kidney cancer incidence, mortality, and cigarette smoking

Elevated kidney cancer incidence, mortality, and risk factor prevalence in the Canadian Aboriginal population are unanimous findings in the literature. There is sufficient evidence to correlate elevated incidence and mortality with the disproportionately elevated rate of cigarette smoking, despite some contradictory evidence. As national data on risk factors was found, it is a plausible explanation for the disparities in kidney cancer incidence and mortality observed among Canadian Aboriginals. Although the correlation between diabetes mellitus and kidney cancer is not well-elucidated, increased incidence of end-stage renal disease may lead to increased cystic disease incidence. Thus, the higher incidence of diabetes mellitus in the Aboriginal population may be associated with increased kidney cancer incidence. Although no data was found on kidney cancer survival, further investigation would elucidate this correlation better.

\section{Correlation between prostate cancer incidence and screening}

Prostate cancer among Canadian Aboriginals remained lower when rate ratios were compared provincially, nationally, and internationally, with the exception of one study. When compared nationally and internationally, Canadian First Nations were screened for prostate cancer substantially less. Thus, it is possible that the reduced incidence rate is attributable to the lack of screening among Canadian Aboriginals. However, 
Wong et al.

\begin{tabular}{|c|c|c|c|c|c|c|c|}
\hline Risk factor & Region & Time period & Abor & $\%(95 \% \mathrm{Cl})$ & $\begin{array}{c}\text { Non-Aboriginal \% } \\
(95 \% \mathrm{Cl})\end{array}$ & $\mathbf{R R}(95 \% \mathrm{Cl}) *$ & $\mathbf{p}^{* *}$ \\
\hline $\begin{array}{l}\text { Current } \\
\text { smoking }\end{array}$ & Canada ${ }^{c, 35}$ & 2006-2010 & $\begin{array}{l}\text { Inuit } \\
\text { FN } \\
\text { Métis }\end{array}$ & $\begin{array}{l}49.0(43.9-54.2) \\
40.1(37.8-42.4) \\
36.8(34.7-39.0)\end{array}$ & $\begin{array}{l}21.8(20.8-21.4) \\
21.8(20.8-21.4) \\
21.8(20.8-21.4)\end{array}$ & $\begin{array}{l}2.25(2.11-2.53) \\
1.84(1.82-1.98) \\
1.69(1.67-1.82)\end{array}$ & $\begin{array}{l}<0.0001 \\
<0.0001 \\
<0.0001\end{array}$ \\
\hline $\begin{array}{l}\text { Current } \\
\text { smokinga }\end{array}$ & Ontario ${ }^{c, 35}$ & 2006-2010 & $\begin{array}{l}\text { Inuit } \\
\text { FN } \\
\text { Métis }\end{array}$ & $\begin{array}{c}39(16.3-61.8) \\
41.5(37.4-45.7) \\
34.5(29.8-39.2)\end{array}$ & $\begin{array}{l}21.8(20.8-21.4) \\
21.8(20.8-21.4) \\
21.8(20.8-21.4)\end{array}$ & $\begin{array}{l}1.79(0.78-2.89) \\
1.90(1.80-2.14) \\
1.58(1.43-1.83)\end{array}$ & $\begin{array}{c}0.0811 \\
<0.0001 \\
<0.0001\end{array}$ \\
\hline $\begin{array}{l}\text { Current } \\
\text { smoking }^{\text {a }}\end{array}$ & Yukon ${ }^{c, 35}$ & 2006-2010 & $\begin{array}{l}\text { FN } \\
\text { Métis }\end{array}$ & $\begin{array}{l}51.2(46.1-56.2) \\
50.9(36.4-65.5)\end{array}$ & $\begin{array}{l}26(22.8-29.3) \\
26(22.8-29.3)\end{array}$ & $\begin{array}{l}1.97(1.92-2.02) \\
1.96(1.60-2.24)\end{array}$ & $\begin{array}{l}<0.0001 \\
<0.0001\end{array}$ \\
\hline $\begin{array}{l}\text { Current } \\
\text { smoking }^{\text {a }}\end{array}$ & $\begin{array}{l}\text { Northwest } \\
\text { Territories }^{\mathrm{c}, 35}\end{array}$ & 2006-2010 & $\begin{array}{l}\text { Inuit } \\
\text { FN } \\
\text { Métis }\end{array}$ & $\begin{array}{l}54.5(47.1-61.9) \\
51.6(45.9-57.4) \\
36.7(28.8-44.7)\end{array}$ & $\begin{array}{l}25.9(22.8-29.0) \\
25.9(22.8-29.0) \\
25.9(22.8-29.0)\end{array}$ & $\begin{array}{l}2.10(2.07-2.13) \\
1.99(1.98-2.01) \\
1.42(1.26-1.54)\end{array}$ & $\begin{array}{l}<0.0001 \\
<0.0001 \\
<0.0001\end{array}$ \\
\hline $\begin{array}{l}\text { Current } \\
\text { smoking }^{\mathrm{a}}\end{array}$ & Nunavut ${ }^{\mathrm{c}, 35}$ & 2006-2010 & Inuit & $65.2(61.2-69.2)$ & $32.0(24.4-39.7)$ & $2.04(1.74-2.51)$ & $<0.0001$ \\
\hline $\begin{array}{l}\text { Current } \\
\text { smoking }^{\mathrm{a}}\end{array}$ & Nunavut ${ }^{\mathrm{d}, 29}$ & 2007-2011 & $\begin{array}{l}\text { FN } \\
\text { Métis }\end{array}$ & $\begin{array}{l}44.9(39.1-50.7) \\
42.9(36.1-49.6)\end{array}$ & $\begin{array}{l}26.2(25.3-27.1) \\
26.2(25.3-27.1)\end{array}$ & $\begin{array}{l}1.71(1.55-1.87) \\
1.64(1.43-1.83)\end{array}$ & $\begin{array}{l}<0.0001 \\
<0.0001\end{array}$ \\
\hline $\begin{array}{l}\text { Current } \\
\text { smoking }^{\mathrm{b}}\end{array}$ & Canada $^{\mathrm{c}, 3}$ & 2000-2001 & $\begin{array}{l}\text { North } \\
\text { South }\end{array}$ & $\begin{array}{l}52.5(50.0-55.0) \\
45.4(42.4-48.4)\end{array}$ & $\begin{array}{l}29.9(26.5-33.3) \\
22.4(22.0-22.8)\end{array}$ & $\begin{array}{l}1.76(1.65-1.89) \\
2.03(1.93-2.12)\end{array}$ & $\begin{array}{l}<0.0001 \\
<0.0001\end{array}$ \\
\hline $\begin{array}{l}\text { Current } \\
\text { smoking }^{b}\end{array}$ & Canada ${ }^{\mathrm{c}, 3}$ & 2005-2006 & $\begin{array}{l}\text { North } \\
\text { South }\end{array}$ & $\begin{array}{l}50.2(45.7-54.8) \\
36.2(33.7-38.6)\end{array}$ & $\begin{array}{l}23.5(20.1-26.9) \\
17.6(17.3-18.0)\end{array}$ & $\begin{array}{l}2.14(2.04-2.27) \\
2.06(1.95-2.14)\end{array}$ & $\begin{array}{l}<0.0001 \\
<0.0001\end{array}$ \\
\hline $\begin{array}{l}\text { Obesity ( } \geq 18 \\
\text { years) }\end{array}$ & Ontario ${ }^{\mathrm{d}, 29}$ & 2007-2011 & $\begin{array}{l}\text { FN } \\
\text { Métis }\end{array}$ & $\begin{array}{l}33.4(27.2-39.5) \\
27.8(21.3-34.4)\end{array}$ & $\begin{array}{l}18.9(18.2-19.6) \\
18.9(18.2-19.6)\end{array}$ & $\begin{array}{l}1.77(1.50-2.02) \\
1.47(1.17-1.76)\end{array}$ & $\begin{array}{c}<0.0001 \\
0.0479\end{array}$ \\
\hline Obesity & Canada ${ }^{\mathrm{c}, 3}$ & 2000-2001 & $\begin{array}{l}\text { North } \\
\text { South }\end{array}$ & $\begin{array}{l}20.2(18.1-22.4) \\
22.7(20.1-25.2)\end{array}$ & $\begin{array}{l}18.5(15.9-21.0) \\
21.1(18.3-23.9)\end{array}$ & $\begin{array}{l}1.09(1.07-1.14) \\
1.08(1.05-1.10)\end{array}$ & $\begin{array}{l}<0.0001 \\
<0.0001\end{array}$ \\
\hline Obesity & Canadac ${ }^{c, 3}$ & 2005-2006 & $\begin{array}{l}\text { North } \\
\text { South }\end{array}$ & $\begin{array}{l}25.4(20.5-30.2) \\
25.3(23.2-27.4)\end{array}$ & $\begin{array}{l}12.3(12.0-12.5) \\
15.6(15.2-15.9)\end{array}$ & $\begin{array}{l}2.07(1.71-2.42) \\
1.62(1.53-1.72)\end{array}$ & $\begin{array}{l}<0.0001 \\
<0.0001\end{array}$ \\
\hline Hypertension & Canada ${ }^{\mathrm{c}, 3}$ & 2000-2001 & $\begin{array}{l}\text { North } \\
\text { South }\end{array}$ & $\begin{array}{c}9.4(7.8-11.1) \\
11.8(9.7-14.0)\end{array}$ & $\begin{array}{c}9.4(7.6-11.2) \\
14.4(14.1-14.7)\end{array}$ & $\begin{array}{l}1.00(0.99-1.03) \\
0.82(0.69-0.95)\end{array}$ & $\begin{array}{c}1 \\
0.0149\end{array}$ \\
\hline Hypertension & Canada ${ }^{\mathrm{c}, 3}$ & 2005-2006 & $\begin{array}{l}\text { North } \\
\text { South }\end{array}$ & $\begin{array}{c}10.9(8.3-13.5) \\
14.4(12.9-16.0)\end{array}$ & $\begin{array}{c}11.3(9.3-13.2) \\
17.0(16.7-17.3)\end{array}$ & $\begin{array}{l}0.96(0.89-1.02) \\
0.85(0.77-0.92)\end{array}$ & $\begin{array}{c}0.243 \\
0.0004\end{array}$ \\
\hline
\end{tabular}

*Rate ratio (RR) was determined by dividing Aboriginal \% by Non-Aboriginal \%, with the $95 \%$ Confidence Interval (Cl) of the RR determined in a similar manner with the values of the Cls from the Aboriginal \% and Non-Aboriginal \%. All RRs were rounded to the nearest hundredth; ${ }^{* *}$ differences in rates were tested for significance assuming independence of crude and age-

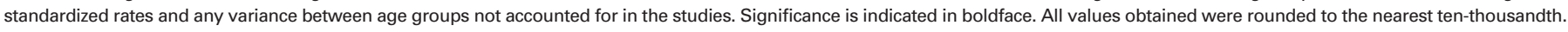
${ }^{3}$ Crude rates. The study population aged 20 years or older was divided by region into those residing in Northern Canada (defined as Yukon, Northwest Territories and Nunavut) or Southern

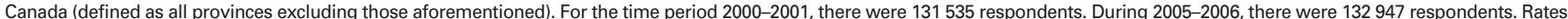
were extracted from the Canadian Community Health Survey (2000-2001 and 2005-2006). ${ }^{35}$ Standardized to the 2006 Canadian Census population. Aboriginal population: 1172790 (698 025

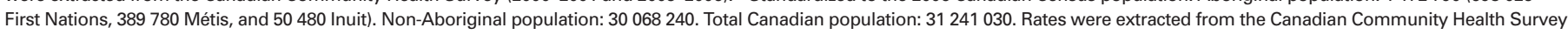

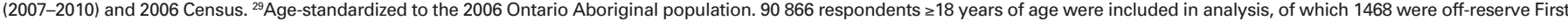
Nations and 990 were Métis. Rates were extracted from the Canadian Community Health Survey (2007-2011). ${ }^{\mathrm{a} D a i l y}$ or occasional; ${ }^{\mathrm{b}} \mathrm{daily} ;{ }^{\mathrm{c}} \mathrm{inclusive}$ of males and females; ${ }^{\mathrm{d}}$ males only. Cl: confidence interval; FN: First Nations; RR: relative risk.

in a population with elevated rates of comorbidities, reduced PSA screening is not unusual. Moreover, lower incidence of prostate cancer can be accounted for by improved data collection methods and coding practices. Prostate cancer is often asymptomatic, which makes screening and early detection key components of reduced mortality and increased survival rates, both observed in the Aboriginal population. ${ }^{38}$ As prostate cancer primarily manifests in men over the age of 55, PSA and DRE use in the Aboriginal population requires further monitoring. ${ }^{5}$
Correlation between prostate cancer mortality, survival, and treatment

Interestingly, lower mortality and poorer survival were concurrently observed in the Canadian Aboriginal population. As survival is a related measure of mortality in a given population, this may indicate the prevalence of prognostic factors for mortality and survival, such as chronic comorbidities in the patient population. Perhaps a more likely explanation to account for the temporal variance between studies may be that Canadian Aboriginals have poorer long-term prognosis due to disparities in treatment accessibility, time, and/or response. Although treatment was not investigated in this review, this is an area of clinical interest for further investigation. Survival must be properly defined in future studies to support these hypotheses. 


\section{Limitations}

Many studies identified through the literature search presented data on cancer(s) other than that of the prostate or kidney, resulting in exclusion. Of those that met the inclusion criteria and were included in the review, the inconsistent reporting of rates limits the interpretation of the rate ratios calculated. Statistical significance could not be determined for several studies, as confidence intervals were not specified or appropriately defined. While the Aboriginal population was fully described across all included studies, the comparative population lacked similar descriptive depth. Population sizes were missing in many studies as well.

A further limitation of this review is the lack of national data on incidence, mortality, and survival on Aboriginals of Canada and other countries. It is clear that valid comparisons nationally and internationally cannot be made without regulated testing and screening practices, as well as proper case documentation.

\section{Conclusion}

This systematic review is the first of its kind to address prostate and kidney cancer disparities in Canada's Aboriginal population and understand them through international comparison. While three evidence-based correlations are made - between prostate cancer incidence and screening; prostate cancer morality, survival, and treatment; and kidney cancer incidence, mortality, and cigarette smoking - there are numerous limitations to the evidence. Although differences in ASRs can be identified, they are not conclusively representative of trends. Despite such limitations, this systematic review unanimously found disparities among the Canadian Aboriginal population, including elevated kidney cancer incidence; mortality and risk factor prevalence; and inferior prostate cancer incidence, mortality, survival, and screening. Based on this review, it is clear that further study is required to better elucidate the epidemiology of prostate and kidney cancer among Canadian Aboriginals.

Competing interests: The authors report no competing personal or financial interests.

This paper has been peer-reviewed.

\section{References}

1. Statistics Canada. Aboriginal peoples in Canada: First Nations people, Métis, and Inuit. [cited 2016 Aug 2]. http://www12.statcan.gc.ca/nhs-enm/2011/as-sa/99-011-x/99-011-x2011001-eng.pdf. Accessed June 12, 2016

2. $\mathrm{Ng}$ CS, Wood CG, Silverman PM, et al. Renal cell carcinoma: Diagnosis, staging, and surveillance. Am J Roentgenol 2008;191:1220-32. https://doi.org/10.2214/AJR.07.3568
3. Lix LM, Bruce $S$, Sarkar, J. Risk factors and chronic conditions among Aboriginal and non-Aboriginal populations. Health Rep 2009;20:21-9.

4. Patel AR, Klein EA. Risk factors for prostate cancer. Nat Clin Pract Urol 2009;6:87-95. https://doi.org/10.1038/ncpurol290

5. Gann PH. Risk factors for prostate cancer. Rev Urol 2002;4:S3-10.

6. Villeneuve PJ, Johnson KC, Kreiger N, et. al. Risk factors for prostate cancer: Results from the Canadian National Enhanced Cancer Surveillance System. Cancer Causes Control 1999;10:355-67. https://doi.org/10.1023/A:1008958103865

7. Altman DG, Bland, JM. How to obtain the confidence interval from a p value. BMJ 2011:343:d2090. https://doi.org/10.1136/bmi.d2090

8. Izawa Jl, Klotz L, Siemens R, et al. Prostate cancer screening: Canadian guidelines 2011. Can Urol Assoc J 201 1;5:235-40. https://doi.org/10.5489/cuaj.11134

9. Pron G. Prostate-specific antigen-based population screening for prostate cancer: An evidence-based analysis. Ont Health Technol Assess Ser 2015:15:1-64.

10. Mahoney MC, Michalek AM. A meta-analysis of cancer incidence in United States and Canadian native populations. Int J Epidemiol 1991;20:323-7. https://doi.org/10.1093/iie/20.2.323

11. Kue Young T, Kelly JJ, Friborg J, et al. Cancer among circumpolar populations: An emerging public health concern. Int I Circumpolar Health 2016;75:29787. https://doi.org/10.3402/iich.v75.29787

12. Kabaria R, Klaassen Z, Terris MK. Renal cell carcinoma: Links and risks. Int J Nephrol Renovasc Dis 2016;9:45-52

13. Marreft LD, Chaudhry M. Cancer incidence and mortality in Ontario First Nations, 1968-1991 (Canada). Cancer Causes Control 2003;14:259-68. https://doi.org/10.1023/A:1023632518568

14. Nishri ED, Sheppard AJ, Withrow DR, et al. Cancer survival among First Nations )

15. Louchini R, Beaupré M. Cancer among Aboriginal people living on reserves and in Northern villages in Québec, 1984-2004. Cancer Causes Control 2009;14:259-68.

16. Louchini R, Beaupré M. Cancer incidence and mortality among Aboriginal people living on reserves and northern villages in Quebec, 1988-2004. Int I Circumpolar Health 2008;67:445-51. https://doi.org/10.3402/iich.v67i5.18355

17. Sanchez-Ramirez $D C$, Colquhoun A, Parker $S$, et al. Cancer incidence and mortality among the Métis population of Alberta, Canada. Int I Circumpolar Health 2016;75:1-6. https://doi.org/10.3402/iich. v75.30059

18. Bramley D, Heber P, Jackson R, et al. Indigenous disparities in disease-specific mortality, a cross-country comparison: New Zealand, Australia, Canada, and the United States. N Z Med J 2004;117:U1215.

19. Espey D, Paisano R, Cobb N. Regional patterns and trends in cancer mortality among American Indians and Alaska Natives, 1990-2001. Cancer 2005;103:1045-53. https://doi.org/10.1002/cncr.20876

20. Dennis TD. Cancer stage at diagnosis, treatment, and survival among American Indians and non-American Indians in Montana. Cancer 2000;89:181-6. https://doi.org/10.1002/10970142(20000701)89:1<181::AID-CNCR24>3.0.C0;2-H

21. Lanier AP, Blot WJ, Bender TR, et al. Cancer in Alaskan Indians, Eskimos, and Aleuts. J Natl Cancer Inst 1980;65:1157-9.

22. Mahoney MC, Michalek AM, Cummings KM, et al. Cancer surveillance in a northeastern native American population. Cancer 1989;64:191-5. https://doi.org/10.1002/1097-0142(19890701)64:1<191::AlDCNCR2820640133>3.0.C0;2-L

23. Norsted TL, White E. Cancer incidence among Native Americans of Western Washington. Int J Epidemiol 1989;18:22-7. https://doi.org/10.1093/iie/18.1.22

24. Young TK, Frank JW. Cancer surveillance in a remote Indian population in Northwestern Ontario. Am J Public Health 1983;73:515-20. https://doi.org/10.2105/AJPH.73.5.515

25. Young TK, Choi NW. Cancer risks among residents of Manitoba Indian reserves, 1970-79. Can Med Assoc J 1985; 132:1269-72.

26. Sorem KA. Cancer incidence in the Zuni Indians of New Mexico. Yale J Biol Med 1985:58:489-96.

27. Lanier A. Survey of cancer incidence in Alaskan Natives. Natl Cancer Inst Monogr 1977;47:87-8.

28. Morrell S, You H, Baker D. Estimates of cancer incidence, mortality, and survival in aboriginal people from NSW, Australia. BMC Cancer 2012;12:168. https://doi.org/10.1186/1471-2407-12-168

29. Withrow DR, Amartey A, Marrett LD. Cancer risk factors and screening in the off-reserve First Nations, Metis and non-Aboriginal populations of Ontario. Chronic Dis Ini Can 2014;34:103-12.

30. Farmer DF, Bell RA, Stark N. Cancer Screening among Native Americans in Eastern North Carolina. J Health Care Poor Underserved 2005;16:634-42. https://doi.org/10.1353/hpu.2005.0094

31. Balajadia RG, Wenzel L, Huh J, et al. Cancer-related knowledge, attitudes, and behaviours among Chamorros on Guam. Cancer Detect Prev 2008;32:4-15. https://doi.org/10.1016/i.cdp.2007.12.002

32. Odedina FT, Yu D, Akinremi TO, et al. Prostate cancer cognitive-behavioural factors in a West African population. J Immigr Minor Heal 2009;11:258-67. https://doi.org/10.1007/s10903-008-9212-9

33. Kidney Cancer Canada. Kidney Cancer Fact Sheet. [cited 2016 Aug 10]. https://www.kidneycancercanada.ca/media/files/315.pdf. Accessed June 18, 2016. 
Wong et al.

34. National Center for Chronic Disease Prevention and Health Promotion. The Health Consequences of Smoking - 50 Years of Progress: A Report of the Surgeon General. Centers for Disease Control and Prevention (US) 2014:1-36.

35. Physicians for a Smoke-Free Canada. Smoking among Aboriginal Canadians. [cited 2016 Aug 10]. http://www.smoke-free.ca/factsheets/pdf/cchs/aboriginal.pdf. Accessed June 18, 2016.

36. Canadian Partnership Against Cancer, Screening Action Group. PSA Toolkit: PSA Screening and Testing for Prostate Cancer. [cited 2016 Aug 10]. hitp://www.sasksurgery.ca/pdf/psa-toolkit-prostate-screeningcpac-2009.pdf. Accessed August 2, 2016.

37. First Nations Information Governance Centre. First Nations regional health survey (RHS) phase 2 (2008/10): National report on adults, youth and children living in First Nations communities. [cited 2016 Aug 10]. hitrp://fnigc.ca/sites/default/files/docs/first_nations_regional_health_survey_ths_200810_-_national_report.pdf. Accessed June 12, 2016.
38. American Cancer Society. Kidney Cancer (Adult) - Renal Cell Carcinoma. [cited 2016 Aug 10]. http://www.cancer.org/acs/groups/cid/documents/webcontent/003107-pdf.pdf. Accessed June 16, 2016

39. Canadian Cancer Society. Canadian Cancer Statistics Special topic: Predictions of the future burden of cancer in Canada. Public Heal Agency Canada 2015:1-151.

Correspondence: Dr. Anil Kapoor, Department of Oncology and Surgery, McMaster University, Hamilton, 0N, Canada; akapoor@mcmater.ca

\section{Appendix 1. Risk of bias evaluation criteria}

1. Cohort

a. Inclusion and/or exclusion criteria for the cohort

i. If applicable, reason(s) for exclusion of eligible members of the cohort

b. Demographic information

i. Size of cohort

c. Temporal and regional information

2. Comparison group

a. Inclusion and/or exclusion criteria for the comparison group, or at minimum, why the comparison group was chosen

i. If applicable, reason(s) for exclusion of eligible members of the comparison group

b. Demographic information

i. Similarity to cohort

c. Temporal and regional information

i. Similarity to cohort

3. Generalizability of results

a. Consider demographics of the cohort (see 1b) and intentions of the study

4. Completeness of outcome data

a. Similarity of statistical methods between cohort and comparison group

i. Confidence intervals

ii. Method of standardization

b. Representation of reported rates

c. Similarity of rate reporting between cohort and comparison group

Note: The evaluation criteria were developed independently by the author. Acknowledgement is made to the following source for background information:

Higgins JPT, Green S. Cochrane Handbook for Systematic Reviews of Interventions Version 5.1.0 [updated March 2011; cited Sep 2]. The Cochrane Collaboration, 2011. Available at http://handbook.cochrane.org/. Accessed August 30, 2016. 